\title{
RELATION BETWEEN CHEMICAL CONSTITUTIONS AND ANTIBACTERIAL EFFEÇTS OF USNIC ACID AND ITS DERIVATIVES
}

\author{
(Preliminary report) \\ By Shoji SHIBATA, Tyunoshin UKITA ANd Tomie TAMURA \\ Department of Pharmacy, University of Tokyo \\ YosHIAKI MIURA \\ Department of Biochemistry, University of Tokyo
}

The chemical structures of metabolic products of lichen have been much clarified by the investigations of Asahina, Asano and their collaborators. From the results of their works, the chemical structure of more than fifty lichenic constituents, including fatty acids, depsides, depsidones, pigments of pulvinic acid derivatives, anthraquinones ${ }^{\bar{i} \mathbf{a}}$, phenanthrene-quinone ${ }^{(\mathrm{b})}$, xanthone $^{\mathrm{lc})}$ and diphenylene oxides ${ }^{1 \mathrm{~d})}$ has been proved; they are so numerous and outstanding in their structure that they may well compose a special chemical group in natural products. Moreover, the investigations have brought out an interesting fact that a certain compound in the lichen has some antibiotic activity.

Namely, Fuzikawa has reported the growth inhibiting effects of depsides and phenol carboxylic acid derivative against the molds growing in soy bean sauce (Shôyu) ${ }^{2}$. Asano et. al.3) have confirmed the antibacterial action of lichesteric acid and its derivatives against staphylococci. In United States, Burkholder and Evans ${ }^{4}$ ) showed by the Oxford Cup method the antibacterial effects of aqueous extract of Cladonia species against B. subtilis and Sarcina lutea. Stoll et. al. of Basel, examined many species of lichens and reported that usnic acid has particullarly high potency of antitubercular activity.

In studies 'carried out at about the same time, we have been able to find the high antibacterial action of usnic acid against acid fast bacilli and Staphylococcus aureus, and also it was noticed that there exists a certain relationship between the antibacterial effect and the chemical constitution of usnic acid and its derivatives.

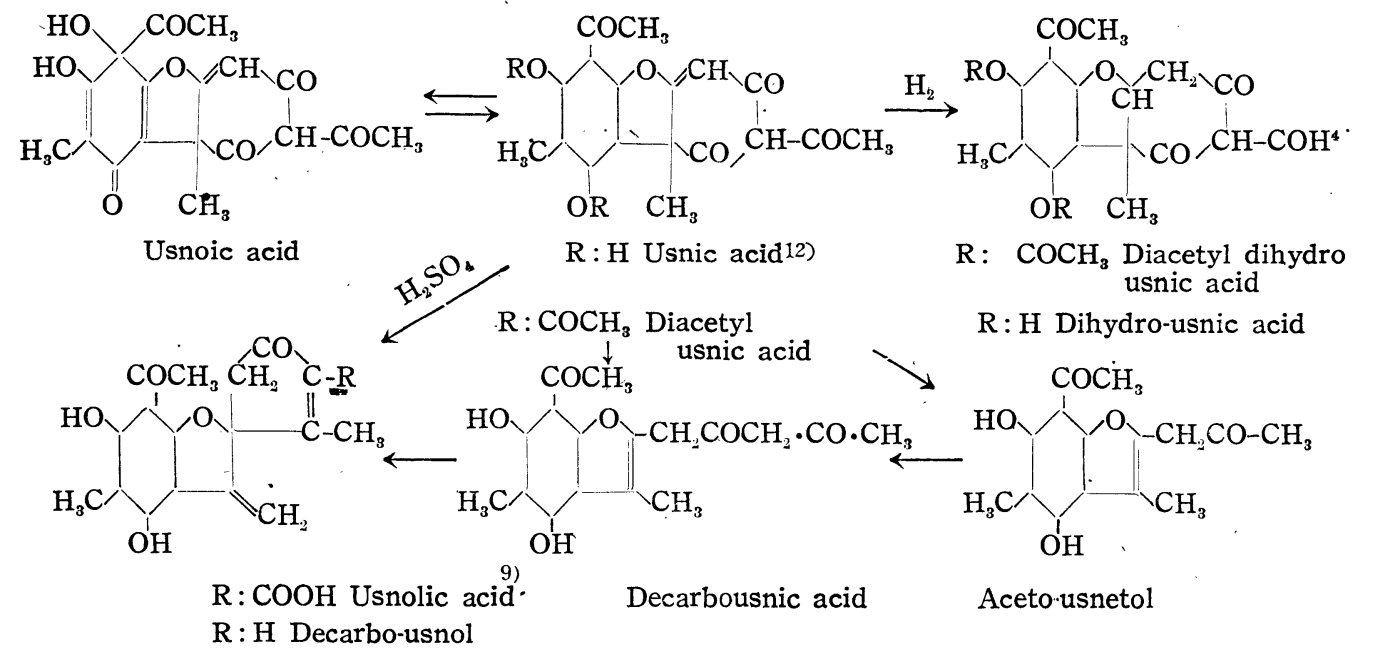


Usnic aid is widely distributed in the lichens such as Usnea, Cladonia, Alectoria, Ramalina Evernia, Parmelia and Lecanora species. It is a yellow colored crystal and has three forms of optical isomers: d-, 1- and racemic.

Since the isolation by Rochleder ${ }^{5}$ ) in 1843 , its chemical structure was intensely studied by Robertson ${ }^{7}$, Asahina ${ }^{89) 10)}$ and Schöpf ${ }^{11) 12)}$, and finally in 1941 the following formula was sugested by Schöpf:

Among many of its derivatives, we have examined the antibacterial actions of d-, 1 -. racem-usnic acid, its sodium salts, d-, 1-diacetyl usnic acid, 1-dihydrousnic acid, diacetyl dihydro-usnic acid, decarbo usnic acid, racem-usnoic acid, and decarbousnol. Except the sodium salts of usnic acids, they are insoluble in water, so in making a. serial dilution we have used $1 \mathrm{mg} / \mathrm{cc}$ of acetone solution as original test liquor. Thus, the acetone solution containing $1 \mathrm{mg}$ of the acid per $1 \mathrm{cc}$ was prepared and diluted with water as given in the table and tested its antibiotic activity for avian type tuberculous bacilli grown in the synthetic Lockemann-Block media ${ }^{13)}$ and for Staphylococcus aureus Terashima cultivated in the ordinary bouillon media (in Table $2-1$ ).

The incubation time was 24 hrs for staphylococci and 10 days for tuberculous bacilli. For staphylococci, we have also made another series of bouillon in which the original dilution were made by adding $5 \% \mathrm{Na}_{2} \mathrm{CO}_{3}$ solution and brought to $\mathrm{pH} 7.6-8.0$. In these ranges, the acids are soluble in water. The results of the experiments are shown in Table 2 .

Table 2. The antibacterial action of usnic acid and its derivatives.

\begin{tabular}{|c|c|c|c|}
\hline \multirow{3}{*}{ Substances } & \multicolumn{3}{|c|}{ Highest dilution inhibiting growth } \\
\hline & \multirow{2}{*}{$\begin{array}{c}\text { Avian type tubercular } \\
\text { bacilli (Incubation } \\
\text { time: } 10 \text { days) }\end{array}$} & \multicolumn{2}{|c|}{$\begin{array}{l}\text { Staph. aureus Terashima } \\
\text { (Incubation time: } 24 \mathrm{hrs} \text { ) }\end{array}$} \\
\hline & & I & II \\
\hline $\begin{array}{l}\text { 1-Usnic acid M.p. } 201^{\circ} \\
{[\alpha]_{D}^{26-479.7}}\end{array}$ & $160 ; 000$ & 320,000 & 204,000 \\
\hline $\begin{array}{l}\text { d-Usnic acid M.p. } 199^{\circ} \\
{[\alpha]_{D}^{20}+468.8}\end{array}$ & 160,000 & 160,000 & 102,000 \\
\hline dl-Usnic acid M.p. $191^{\circ}$ & $160,000 *$ & 160.000 & 1102,000 \\
\hline Na-salt of 1-usnic acid & $160,000 *$ & & 204,800 \\
\hline $\mathrm{Na}$-salt of d-usnic acid & 160,000 & & 102,000 \\
\hline $\begin{array}{l}\text { 1-Diacetyltusnic acid } \\
\text { M.p. } 200^{\circ},[\alpha]_{\mathrm{D}}^{20-}-180.4^{\circ}\end{array}$ & 80,000 & 10,000 & 25,600 \\
\hline $\begin{array}{l}\text { d-Diacety usnic acid } \\
\text { M.p. } 200^{\circ},[\alpha]_{D}^{14}+199.7^{\circ}\end{array}$ & 40,000 & 10,000 & 25,600 \\
\hline $\begin{array}{l}\text { 1-Dihydro usnic acid } \\
\text { M.p. } 149^{\circ},[\alpha]_{D}^{20}-81.1^{\circ}\end{array}$ & 40,000 & 20,000 & 25,600 \\
\hline $\begin{array}{l}\text { d-Diacetyl dihydro } \\
\text { usnic acid M.p. } 150^{\circ}[\alpha]_{\mathrm{D}}^{20}+17.4^{\circ}\end{array}$ & 10,000 & 10,000 & 6,400 \\
\hline Decarbousnic acid M.p. $177^{\circ}$ & $<10,000$ & $<10,000$ & 6,400 . \\
\hline dl-Usnoic acid . M.p. $157^{\circ}$ & $<10,000$ & $<10,000$ & - \\
\hline Decarbo-usnol & $<10.000$ & $<10,000$ & 1,600 \\
\hline
\end{tabular}

* Original test liquoir were aqueous solution. 
It is noticeable that usnic acids are very strong antibiotics even at the dilution of 1:160,000-200,000 against both test organisms. The anti-tubercular activity of $p, p^{\prime}$-diamino diphenyl, sulfone and promin, using the same method, were $1: 500,000$ and $1: 200,000$ repectively.

The antitubercular activity is decreased to one-half or to one-fourth by the acetylation of two hydroxyl groups in the left ring of usnic acid; in the case of dihydro-usnic acid in which the double bond of the right ring is hydrogenated, the action is reduced to one-fourth: By the acetylation of dihydro-usnic acid, the antibacterial activity is reduced to one-sixteenth of the original compound. From these facts, the double bond and hydroxyl groups of usnic acid are assumed to have nearly the equal activity for antibacterial action. Decarbo-usnic acid showed also a weak antitubercular action but the coumaron ring alone could not contribute much to the antibiotic action. Thus, by gradual blocking of the active groups we were able to demonstrate the localization of antibacterial action of usnic acid.

The pharmacological actions of usnic acid and its derivatives were investigated by Mikoshiba ${ }^{14}$ ) leading to the conclusion that it has some papaverine-like action to involuntary muscles but no such high toxicity (L. $\mathrm{D}_{\mathrm{so}}$ for mice is $7.0 \mathrm{mg} / 10 \mathrm{~g}$ by the subcutaneous, and $0.25 \mathrm{mg} / 10 \mathrm{~g}$ by the intraveneous application). Judging from these results, it seems promicing as a new chemotherapeuticum for human tuberculosis. It is interesting to refer in this respect to the fact that a species of lichen, Usnea longissima, has been already used by the Chinese as expectorant under the name of "Sun-Lo", and the powder of raw lichen was also used as popular drug for treatment of ulcer. In 1898, Chiba ${ }^{15}$ ) reported that the tincture of Usnea species was very effective for tuberculous lymphadenitis coli. As to the real applicability of usnic acid for human tuberculosis, the investigation is now being carried out and the result will be reported in near future.

We are indebted to Professors A. Akiba, Y. Asahina, M. Asano, M. Ishidate and K. Kodama for their advices during the experiments and to Drs. M. Yanagita and K. Okazaki for giving us some of the test compounds.

\section{REFERENCES}

1a) Y. Asahina: J. Chem. Soc. Japan, 61, 611, 1940 (in Japanese).

Y. Asahina: "Flechtenstoffe" Fortschritte der'Chemie organischer Naturstoffe, Bd. II; 27-60, 1939 (Julius Springer, Wien).

b) Y. Asahina and S. Shibata: Ber., 72, 1531, 1939.

c) Y. Asahina and H. Nogami: Bull. Chem. Soc. Japan, 17, 202, 1942.

d) S. Shibata: Acta Phytochim. (Tokyo), 14, 9, 177, 1944.

2) F. Fuzikawa and S. Shimamura: J. Pharm. Soc. Japan. 65, 4, 1945 (in Japanese).

3) M. Asano et. al.: "Igakusoran" 1, 41, 1945 (in Japanese).

4) P. R. Burkholder and A. W. Evans: Bull. Torrey Botan. Club, 72, 157, 1945.

5) A. Stoll et. al.: Experimentia, 3, 11, 115, 1947; Chem. Abst. 41, 4534, 1947.

6) Rochleder and Heldt: Ann Chem., 48, 11, 1843.

7) A. Robertson et.' al.: J. Chem. Soc., 714, 1173, 1933; J. Chem. Soc., 1834, 1936 ; J. Chem. Soc., 894, 1937 ; J. Chem. Soc., 306,.1938; J. Chem. Soc., 1594, 1939.

8) Y. Asahina and M. Yanagita: Ber., 69, 1646, 1936; Ber., 70, 66, 1500, 1937; Ber., 71, 2260, 1938; Ber., 78, 1140, 1939 . 
9) Y. Asahina and K. Okazaki: Proc. Imp. Acad. Tokyo, 19, 303, 1943; Y. Asahina and K. Kim: Proc. Imp. Acad. (Tokyo), 20, 371, 1944.

10) M. Yanagita: Ber., 71; 2269, 1938.

11) Schöpf and Heuck: Ann., Chem., 459, 233, 1927.

12) Schöpf and Ross: Ann. Chem. 546, 1, 1941.

13) Block: Helv. Chim. Acta, 27, 413, 1944.

14) K. Mikoshiba: Tokyo Igakukaishi, 47 No. 8 and No. 9, 1933 (in Japanese).

15) K. Chiba: J. Pharm. Soc. Japan, No. 258, 829, 1898.

\title{
A CONTRIBUTION TO THE KNOWLEDGE OF CELL-GRANULE : ON THE "NUCLEOPROTEID-LIKE GRANULE" (MARUI) AND “ $\lambda$-GRANULE” (MARUI)
}

\author{
By KIYOYASU MARUI \\ The Aomori Medical College, Hiromaye
}

I. On the "nucleoproteid-like granule" (marui):

In 1919 while studying at the Neurological Laboratory of the Phipps Psychiatric Clinic, the Johns Hopkins Hospital on the morphological changes of the synapse of Mauthner cells of catfish (Ameiurus nebulosus) in case of over-activity Marui demonstrated in the protoplasm of the so-called amoeboid as well as pre-amoeboid neuroglia cells a new granule, which can be stained by thionin with beautiful metachromatic-basophile nuance; he found then the same sort of granules in the cell-body of ectodermal and mesodermal granular cells, which appear in human brains suffering from various pathological conditions. Further he discovered the similar granule in liver cells of mammals, which seemed very remarkable to him. On the basis of his findings, that those granules are morphølogically as well as micro-histo-chemically quite identical with Nissl granules of nerve cells, the fine constituent elementsof Nissl body, and also the fact, that the Nissl substance was regarded by Held and many other authors chemically as belonging to the category of nucleoproteids, he decided to call this kind of granule "Nucleoproteid-like granule" according to the suggestion of Dr. Adolf Meyer. Further investigation on this granule, which lasted about 30 years, led him to the following rather interesting conclusions:

1) The "nucleoproteid-like granule" (Marui), which is to be regarded morphologically as well as micro-histo-chemically identical with the Nissl granule, which latter was considered for a long time as s specific constituent of nerve cells, appears under certain pathological conditions in neuroglia cells, ectodermal and mesodermal granular cells, and Kuppfer stellate cells of liver; the same granules were found physiologically in liver cells of adult mammals and the fact is especially worthy of note, that in certain animals (rabit, white rat, goat, etc.) they collect together to groups or heaps, which look quite like the Nissl body of nerve cells and also distributed in liver cells not unlike the latter. 